\title{
Pengaruh Meme Terhadap Identitas Pemuda Muslim Nusantara: Telaah Respons Konten Instagram
}

\author{
Muhammad Fathur Rozaq \\ Universitas Islam Negeri Sunan Kalijaga Yogyakarta \\ fathurrozaq1994@gmail.com
}

Abstract: $\quad$ Now Instagram is a popular social media platform that is popular and influential, especially among youth. Instagram contains less than two minutes of video content, photos, and caricature images and a series of words, wisdom, humor, even satire, all of which are often called memes. whether the idea or idea carried by a particular account is accepted, appreciated, or otherwise gets resistance from its followers. To find out, this requires observing their actions in response to certain content on a particular account. This article will discuss how Muslim youth in the country respond to ideas spread on Instagram. by looking at how they like and comment on content. The study uses a descriptive analysis approach. Three things the authors capture from this phenomenon. First, the discourse most favored by Muslim youth is the issue of romance. Second, thinking power is less critical especially when dealing with dogmatic content. Third, their attitude tends to be quiet when treated with commodified content. And it can be concluded that love issues are most in demand than religious issues and other issues.

Abstrak: Instagram dewasa ini menjadi platform sosial media yang banyak digemari dan berpengaruh terutama di kalangan pemuda. Instagram berisi konten video berdurasi kurang dari dua menit, foto, dan gambar karikatur serta rangkaian kata-kata, bijak, humor, bahkan satire yang kesemuanya itu sering disebut meme. apakah ide atau gagasan yang diusung oleh akun tertentu itu diakseptasi, diapresiasi, atau sebaliknya mendapat resistansi dari para pengikutnya. Untuk mengetahui ini diperlukan pengamatan 
atas tindakan mereka menyikapi konten tertentu pada akun tertentu. Artikel ini akan membahas bagaimana pemuda Muslim tanah air merespons ide yang tersebar dalam Instagram. dengan melihat cara mereka menyukai dan memberikan komentar terhadap suatu konten. Penelitian menggunakan pendekatan deskriptip analisis. Tiga hal yang penulis tangkap dari fenomena ini. Pertama, diskursus yang paling digemari pemuda Muslim yakni isu-isu percintaan. Kedua, daya pikir yang kurang kritis terlebih ketika berhadapan dengan konten dogmatik. Ketiga, sikap mereka yang cenderung diam saat disuguhi konten komodifikatif. Dan dapat disimpulkan bahwa isu-isu percintaan yang paling diminati daripada isu religi dan isu yang lainnya.

Kata kunci: Instagram, meme, identitas, pemuda Muslim.

\section{A. Pendahuluan}

Pada September 2014 Instagram memiliki 200 juta pengguna dengan 65\% pengguna berada di luar Amerika Serikat, dengan 20 milyar foto dibagikan, rata-rata 1,6 miliar like per hari, dan sedikitnya 60 juta gambar diunggah per harinya. ${ }^{1}$ Terhitung sampai Juni 2018 jumlah pengguna Instagram di seluruh dunia meninggkat drastis menjadi 1 miliar pengguna. Indonesia menempati peringkat empat pengguna terbanyak Instagram dengan jumlah 56 juta pengguna, di bawah India (59 juta), Brazil (61 juta), dan Amerika Serikat (120 juta), pada survey April 2018.

Adapun mayoritas pengguna kaum millenial berusia antara 1829 tahun. $^{2}$ Chris Chesher menganggap bahwa Instagram adalah aplikasi yang mendagangkan nostalgia instan. Chesher juga mengungkapkan jika Instagram adalah hasil hibridasi dari kamera polaroid dan telegram, yakni aplikasi neo-retro yang membuat gambar instan dapat ditransmisikan kemanapun. ${ }^{3}$ Untuk itu Michele

${ }^{1}$ Tim Highfield dan Tama Leaver, "A Methodology for Mapping Instagram Hashtags," Journal of Queesnland University of Technology Vol. 20, no. 1 (2015): h. 10 .

${ }^{2}$ Diakses 6 Juli 2018, http://www.statista.com/statistics/578364/countrieswith-most-instagram-users/.

${ }^{3}$ Chris Chesher, "Between Images and Information: The iPhone Camera in the History of Photography," dalam Studying Mobile Media: Cultural Technologies, Mobile Communication, and the iPhone, ed. oleh Larissa Hjorth, Jean Burgess, dan Ingrid Richardson (London: Routledge, 2012), h.108. 
Zappavigna menggolongkan Instagram sebagai aplikasi penyedia jaringan sosial dalam bentuk wahana distribusi foto. Di mana media ini digunakan dan dibagikan oleh para audien untuk tujuan mereka pribadi yang termasuk bagian dari partisipasi budaya. ${ }^{4}$

Instagram berisi konten video berdurasi kurang dari dua menit, foto, dan gambar karikatur atau rangkaian kata-kata; bijak; humor; bahkan satire yang sering disebut meme. Kata meme menyebar begitu cepat di Nusantara dan dimengerti dalam pengertian sempitnya yakni konten gambar, video, atau teks yang disebarkan oleh netizen. Kata meme dipopulerkan oleh Richard Dawkins dalam karyanya The Selfish Gene yang terbit pertama kali pada 1976. Kata meme sendiri dibentuk oleh Dawkins dari kata Yunani Mimeme yang secara harfiah berarti imitasi. Ia menghendaki bentukan kata monosilabel agar dekat dengan ejaan kata gene, maka jadilah kata meme. Dawkins memberi pengertian bahwa meme menyebarkan dirinya dari pikiran manusia satu ke yang lainnya melalui proses imitasi. ${ }^{5}$ Richard Brodie bahkan sampai memberikan beberapa pengertian yang berasal dari disiplin ilmu berbeda. Brodie mengutip Dawkins untuk definisi biologis dari meme yakni unit dasar dari transmisi budaya atau bisa disebut juga peniruan. Secara psikologis ia mengutip Plotkin bahwa definisi meme adalah bagian dari turunan budaya yang dapat dianalogikan dengan gen, bentuk representasi internal dari pengetahuan. Ia mengutip definisi meme secara kognitif dari Dennett bahwa meme adalah ide, semacam ide kompleks yang membentuk dirinya menjadi unit ingatan yang khas. Hal ini disebarkan oleh wahana yang merupakan manifestasi fisik dari meme. Ia kemudian menyimpulkan bahwa meme adalah unit informasi dalam pikiran yang wujudnya memengaruhi meskipun sekedar salinan dari pikiran itu sendiri yang diciptakan pada pikiran lain. ${ }^{6}$

Faktanya dengan munculnya Instagram, sebagai salah satu platform sosial media yang banyak mengakomodir meme ini_adakah Instagram menjadi platform layaknya media lain yang cenderung manipulatif seperti yang dikatakan oleh Pam Nilan. Bahwa media

${ }^{4}$ Michele Zappavigna, "Social Media Photography: Construing Subjectivity in Instagram Images," Sage Journa: Visual Communication Vol. 15, no. 3 (2016): h.3.

${ }^{5}$ Richard Dawkins, The Selfish Gene (Oxford: Oxford University Press, 2006), h.192.

${ }^{6}$ Richard Brodie, Virus of The Mind: The New Science of The Meme (London: Hay House, 2009), h.5-11. 
menjadikan pemuda sebagai target komersialisasi industri melalui adanya iklan. Selain itu juga mendorong moral panik mengenai apa yang harus pemuda lakukan dengan arahan yang massive menunjuk kepada pilihan gaya hidup dan konsumsi. ${ }^{7}$ Karena dengan Adanya Instagram membuka ruang baru dalam berekspresi melaui teks, gambar, foto, dan sebagainya,

Sementara di sisi lain dengan adanya peningkatan tekhnologi hingga dalam taraf personalisasi digital menjadikan tingkat kemungkinan manusia untuk merasakan kehidupannya dalam media semakin tinggi seperti yang dikatakn oleh Mia Lovheim. ${ }^{8}$ Yang kemudian menimbulkan pertanyaan bentukan identitas macam apa yang akan tampak dari meme dalam Instagram.

Kajian tentang Instagram dalam kaitannya dengan agama telah dipaparkan oleh Eva F. Nisa. ${ }^{9}$ Nisa dalam artikelnya memaparkan isu dakwah hijab dan konstelasi di antara akun-akun Instagram yang mengusung tema hijab. Artikel lain karya Taqwim Aminuddin juga membahas Instagram berkenaan dengan isu surat Al-Maidah ayat 51 yang tengah berkembang pada waktu pilkada DKI Jakarta. Ia menyelidiki kontelasi di antara akun-akun yang berbasis pro Muhammadiyah, Nahdhatul Ulama, dan Front Pembela Islam. ${ }^{10}$ Dua artikel tersebut berkutat pada isu yang diusung oleh akun-akun tertentu serta bagaimana akun-akun itu bekerja. Belum tampak jelas bagaimana respons para pengikut akun-akun tersebut menyikapi konten yang mereka hadapi. Sehingga proses resepsi masih buram apakah ide atau gagasan yang diusung oleh akun tertentu itu diakseptasi, diapresiasi, atau sebaliknya mendapat resistansi dari para pengikutnya. Untuk mengetahui ini diperlukan pengamatan atas tindakan mereka menyikapi konten tertentu pada akun tertentu. Maka dari itu Artikel ini bertujuan mengamati bagaimana respons generasi milenial Muslim

7 Pam Nilan dan Michelle Mansfield, "Youth culture and Islam in Indonesia," Wacana Vol. 15, no. 1 (2014): h.4.

${ }^{8}$ Mia Lovheim, "Identity," dalam Digital Reigion: Understanding Religious Practice in New Media World, ed. oleh Heidi A. Campbell (London: Routledge, 2013), h.42.

${ }^{9}$ Eva F. Nisa, "Creative and Lucrative Da'wa: The Visual Culture of Instagram amongst Female Muslim Youth in Indonesia," dalam Asiascape: Digital Asia, vol. Vol. 5 (Leiden: Brill, 2018), h.1-32.

${ }^{10}$ lihat Ahmad Taqwim Aminuddin, "Instagram Bingkai Kasus Agama Di Media Sosial," Jurnal The Mesengger Vol. 9, no. 2 (Juli 2017). 
Indonesia dengan melihat cara mereka menyukai dan memberikan komentar terhadap suatu konten. Penelitian menggunakan pendekatan deskriptip analisis.

\section{B. Pemuda Muslim Baper}

Kata baper sejatinya belum dimasukkan oleh Balai Bahasa kedalam KBBI. meski begitu kata ini sangat sering digunakan di sosial media oleh masyarakat Indonesia terutama oleh pemuda. Kata baper adalah padatan dari frasa bawa perasaan. Sementara pemaknaan kata perasaan dalam frasa bawa perasaan merujuk pada keadaan batin ketika merasai sesuatu. Kata baper sering kali digunakan untuk menilai kadar respons seseorang ketika menghadapi sesuatu. Seorang yang merespons sesuatu dengan emosi tertentu yang ditengarai dari hati dapat dikatakan baper. Titik kunci kata ini terletak pada respons reflektif. Seseorang yang menjalankan suatu hal atau kegiatan dengan sepenuh hati atau batin disebut tulus. Ia tidak disebut baper karena ia menjalankan sesuatu tersebut bukan dalam rangka merespons sesuatu. Sering kali kata baper disandingkan dengan perasaan seseorang dalam hal asmara meskipun didapati juga dalam perkara lain seperti rasa marah dan lain sebagainnya.

Para pengguna Instagram cenderung responsif ketika menghadapi konten yang bertendensi membuat baper. Dibandingkan dengan konten-konten lain yang menyajikan informasi seperti riwayat, kaul ulama, dan perihal amalan tertentu konten pembuat baper lebih banyak mendapat respons berupa like dan komentar dari para pengguna Instagram. Konten baper Islami memadukan dua elemen penting untuk meraup respons dari para pengguna Instagram, isu percintaan khas remaja dengan nilai normatif Islam. Proses alami perkembangan pemuda terkait ketertarikan mereka terhadap lawan jenis diarahkan menuju titik ideal menurut akun Islam tersebut. Kata-kata dalam konten baper dimodifikasi sedemikian rupa hingga terlihat Islami atau layaknya ajaran normatif Islam meskipun sering kali hanya berupa pemikiran pribadi. 


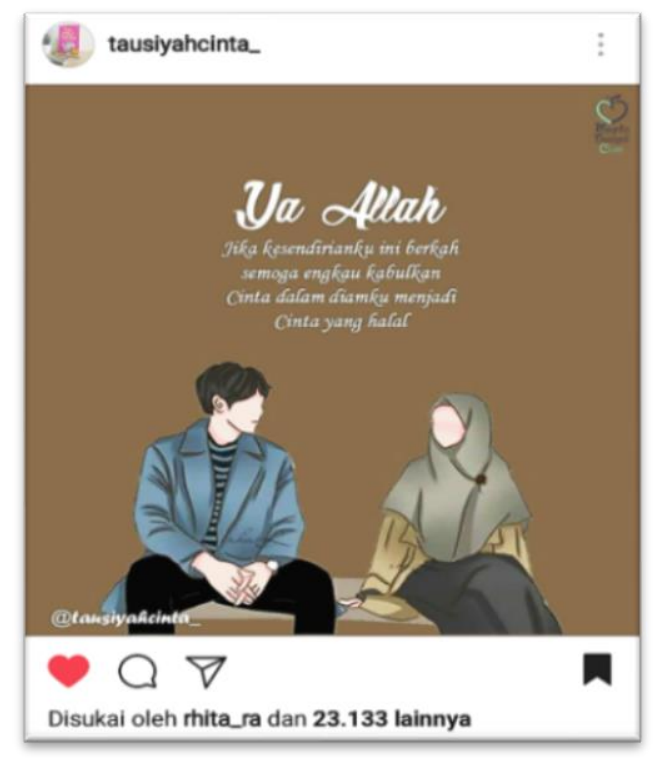

Gambar 1. Konten baper akun tausiyahcinta_

Gambar 1.1 adalah konten yang diunggah oleh akun tausiyahcinta_ pada 05 Juli 2018. Dalam empat hari konten ini telah mendapat dua puluh tiga ribu lebih like dan seratus delapan puluh komentar dari para pengguna Instagram. Konten ini menggambarkan dua sosok pemuda di mana sosok perempuan memaki kerudung sebagai simbol dari nilai Islam. Memakai kata pembuka, "Ya Allah," yang menjurus sebagai pembuka dalam doa dan isi doa itu sendiri, "jika kesendirianku ini adalah hikmah semoga engkau kabulkan cinta dalam diamku menjadi cinta yang halal." Doa tersebut setidaknya mengandung dua kata dan frasa inti yakni kesendirian dan cinta dalam diam. Kata kesendirian adalah bentuk nyata dari gambaran larangan berkhalwat atau berduaan bagi lawan jenis di tempat sepi. Sementara frasa cinta dalam diam menggambarkan nalar pemuda kasmaran. Konten ini dapat menggabungkan antara gejala alami pemuda yakni ketertarikan kepada lawan jenis dengan apa yang mereka andaikan dengan nilai Islami. Setidaknya konten ini menjadi menarik bagi para pemuda yang tengah berada dalam kesendirian; sedang kagum dengan lawan jenis namun tidak sanggup mengungkapkan; dan ingin mendalami Islam. 
Dari 1.6 juta pengikut akun tausiyahcinta_ kurang dari 3\% yang memberikan respons berupa like dan hanya sepersepuluh dari $1 \%$ yang memberikan komentar pada konten tersebut. Meskipun secara prosentase terhitung sedikit yang memberikan respons catatan ini lebih baik dibanding konten nir-baper.

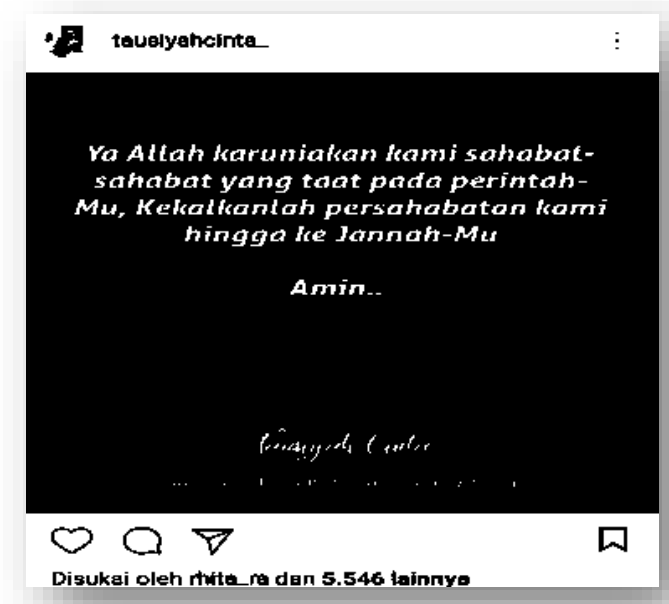

Gambar 2. Konten nirbaper tausiyahcinta_

Gambar 1.2 diunggah bersamaan dengan konten sebelumnya pada gambar 1.1. Konten kali ini senada dengan konten sebelumnya yakni menjurus pada redaksi doa. Perbedaan keduanya terletak pada muatan doa yang mana pada konten kali ini yang dimasukkan adalah muatan bertema persahabatan. Tema persahabatan bisa jadi memang menjadi salah satu isu yang sesuai bagi pemuda namun kali ini tema tersebut kalah dengan tema percintaan pada konten sebelumnya. Satu hal yang signifikan dalam kasus ini yakni konten gambar 1.2 adalah konten nirbaper. Sehingga konten ini hanya mendapat lima ribu lima ratus lebih like dan serartus sembilan belas komentar.

Tidak hanya pada akun tuasiyahcinta, pola pengguna Instagram baper juga nampak pada akun teladan.rasul. Pada akun-akun Islami dengan pengikut yang lebih sedikit pun demikian, meskpiun di sini hanya akan ditampilkan kaun dengan banyak pengikut dengan asumsi bahwa persebaran konten akun tersebut lebih luas. 


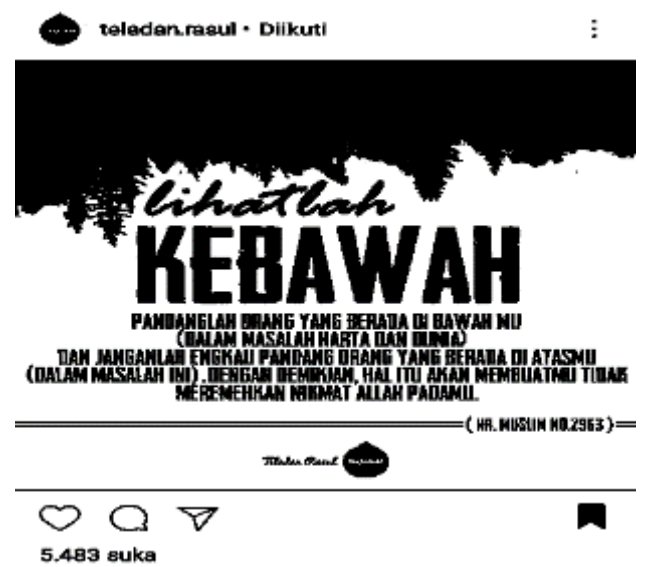

Gambar 3. Konten nirbaper akun teladan.rasul

Konten nirbaper di atas hanya mendapat kurang dari enam ribu like dan tidak lebih dari sepuluh komentar. Pun juga konten-konten di akun ini yang nirbaper tidak jauh berbeda, sedikit saja mendapatkan respons. Berbanding terbalik dengan konten baper yang bisa mendapat lima kali lipat respons melebihi konten nirbaper.

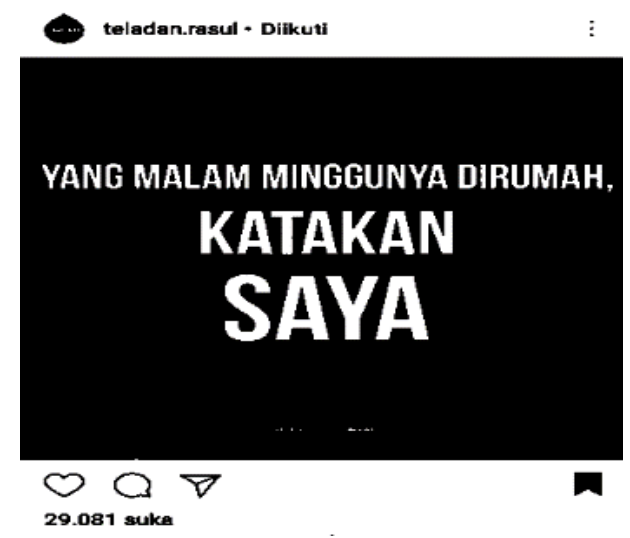

Gambar 4. Konten Baper akun teladan.rasul

Gambar 1.4 termasuk dalam kategori konten pembuat baper dikarenakan pertanyaannya yang menjurus pada klarifikasi siapa sajakah pengikutnya yang masih 'sendiri'. Hanya dalam kisaran dua hari pasca diunggah konten ini telah mendapat dua puluh sembilan ribu lebih like dan seribu enam ratus lebih komentar. Pemuda yang belum atau tidak memiliki pasangan cenderung baper mednapati pertanyaan 
seperti itu. Sehingga tidak mengherankan apabila konten ini mendapatkan banyak respons dari para pengguna Instagram.

Banyaknya respons yang didapat oleh konten bermuatan baper menunjukkan besarnya ketertarikan pengguna dengan perpaduan tema percintaan dengan nilai normatif Islam. Konten baper dalam hal ini menjadi meme karena persebarannya yang subur dan cepat. Konten dengan banyak like akan lebih sering muncul pada laman pengguna Instagram ditambah dengan komentar dari pengguna yang sering kali menandai pengguna lain untuk melihat konten tersebut. Sehingga semakin banyak pengguna yang mengakses konten baper.

\section{B. Kurungan Pasca Kebenaran}

Bruce McComiskey menyatakan bahwa platform sosial media termasuk Instagram mempertahankan penggunaan mereka atas algoritma yang mengarahkan pengguna pada konten yang biasa dilihat atau kunjungi. Informasi yang memadati laman seseorang dipilih dari apa yang juga diakses oleh teman, kontak, dan keluarganya. Tidak ada lagi desentralisasi informasi karena platform ini didesain untuk memaksimalkan waktu penggunanya dengan laman mereka, di mana link lain yang menyelisihi minat pengguna tidak akan muncul dalam tampilan lamannya. ${ }^{11}$ Algoritma buatan mereka seperti halnya penjilat dengan kata-katanya yang selalu manis agar siapapun yang diinginkannya tidak menjauh darinya.

Dalam ruang diskusi mengenai pasca kebenaran satu kata kunci yang tidak pernah lepas dari pembahasan adalah bullshit. ${ }^{12}$ Term ini dipopulerkan oleh Harry G. Frankfurt dalam karyanya On Bullshit. Frankfurt menandaskan bahwa pengujar bullshit tidak memperhitungkan apakah ujarannya benar. Sementara faktanya ujaran tersebut berlainan dengan realitas yang ada. Bagi pengujar tersebut yang terpenting adalah apa yang ada dalam kehendaknya tanpa memikirkan adakah sesuatu itu benar-benar demikian adanya. Esensi bullshit adalah saat ujaran tertentu tidak dapat dikatakan sebagai kebohongan karena sang pengujar sendiri tidak mengetahui mana yang

${ }^{11}$ Bruce McComiskey, Post-Truth Rethoric and Composition (Logan: Utah State University Press, 2017), h.20.

12 James Ball, Post-Truth: How Bullshit Conquered The World (London: Biteback Publishing, 2017), h.8. 
benar. Pernyataan pengujar berkisar bukan pada keyakinan apakah ujaran itu benar atau tidak. Ujaran itu ada tanpa adanya koneksi dengan urusan kebenaran. ${ }^{13}$

Begitu juga dengan konten yang diunggah oleh beberapa akun di Instagram, tidak lepas dari bullshit. Akun penyedia konten Islami pun tidak lepas dari hal ini. Bukan hanya para pengikut akun yang gagap menyebarkan apa yang belum jelas diketahui kebenarannya menganggap konten tersebut bagus untuk disebarkan- tetapi juga pembuat konten itu sendiri yang tergesa-gesa mengunggah sesuatu tanpa melakukan klarifikasi ulang benar tidaknya informasi yang didapatnya.

Akun Instagram yang mengunggah konten berisi riwayat berpeluang besar melakukan bullshit. Aturan ilmu riwayat atau ilmu hadis yang rumit tidak lagi diperhatikan demi keinginan menyebarkan riwayat yang dikehendaki meskipun akun itu sendiri belum mengetahui bagaimana kualitas hadis tersebut. Hal terpenting adalah bagaimana caranya riwayat yang diunggah mendapat respons berlimpah. Pun juga ketika mengunggah konten riwayat hadis rentetan sanad pasti dipotong hingga nama sahabat atau dihilangkan sama sekali. Ini tidak lepas dari minat pengguna Instagram yang cenderung lebih menyukai tulisan pendek. Rangkaian sanad dalam satu hadis jelas akan membuat konten terlihat sangat panjang dan ini berisiko menurunkan minat baca dan respons dari para pengguna.

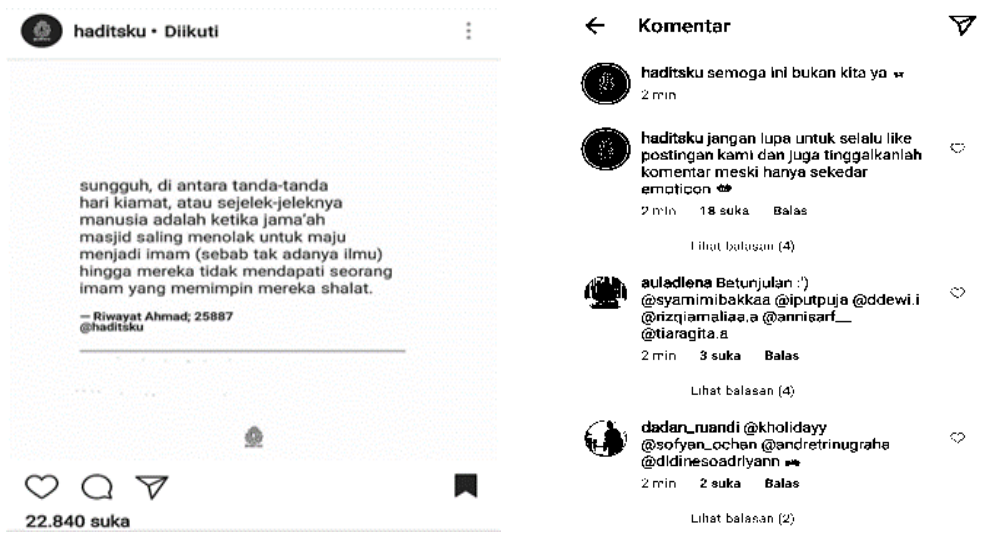

${ }^{13}$ Harry G. Frankfurt, On Bullshit (Princeton: Princeton University Press, 2005), h.31-35. 

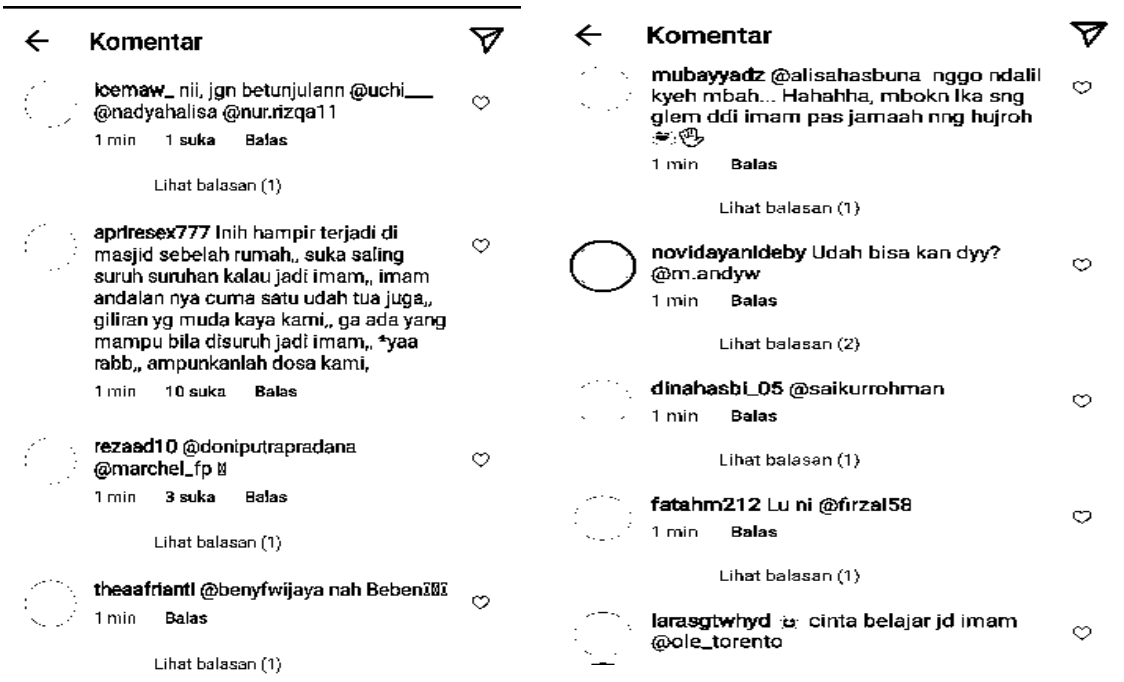

\section{Gambar 5. Konten akun hadtsku}

Gambar 2.1 adalah konten unggahan akun haditsku yang mendapat dua puluh dua ribu like lebih dan lebih dari dua ratus komentar. Konten ini menyebut hadis yang diunggah adalah riwayat yang dikeluarkan oleh Ahmad dengan nomor indeks 25887. Tidak disebut keterangan penerbit, tahun cetak, dan segala keterangan lain agar pembaca pada umumnya bisa melacak sumber mana yang dirujuk oleh akun ini. Telaah lebih lanjut menunjukkan jika hadis di atas benar dikeluarkan oleh Ahmad dalam Musnad-nya. Hadis ini tercantum dalam bab hadis yang diriwayatkan oleh Salamah binti al-Hur, salah satu sahabiyah yang kurang populer. Ahmad hanya mencantumkan dua hadis yang bersinggungan dengan sahabiyah ini, dengan matan senada. Secara berurutan hadis dari Salamah memiliki nomor indeks 27137 dan 27138. ${ }^{14}$ Berbeda dengan nomor indeks yang disebut oleh akun haditsku. Selisih perbedaan nomor hadis terhitung mencolok di angka 1257. Dalam pelacakan lebih lanjut nomor indeks yang digunakan oleh akun haditsku sama dengan nomor hadis dalam aplikasi hadis keluaran Lidwa Pusaka. Sementara dalam ranah akademik referensi hadis dari aplikasi digital dianggap tidak lebih valid dari referensi kitab atau buku

${ }^{14}$ Ahmad bin Muhammad bin Hanbal, Musnad Ahmad, ed. oleh Syuaib alArnaut, vol. Juz 45 (Beirut: Resalah Publisher, 2001), h.111-112. 
asli. Meskipun terdapat beberapa akademisi yang menyinggung tentang perkembangan, verifikasi, hingga autentifikasi hadis di era digita $1{ }^{15}$ belum ada penelitian yang menyinggung sejauh mana validitas sebuah aplikasi hadis termasuk Lidwa Pusaka. Sementara di sisi lain validitas teks hadis dalam kitab atau buku sudah tidak diragukan sama sekali.

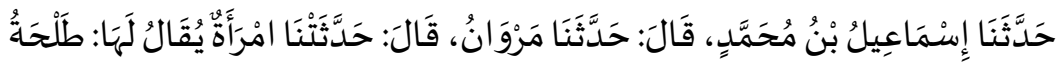

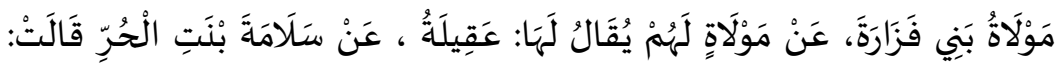

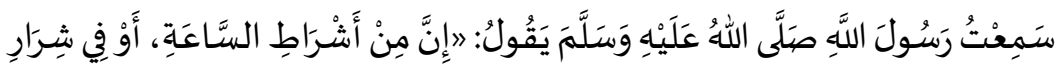

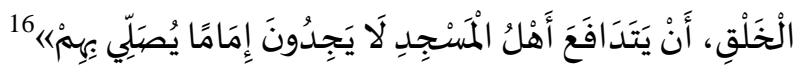

Telah menceritakan kepada kami Ismail bin Muhammad dia berkata, telah menceritakan kepada kami Marwan dia berkata, telah menceritakan kepada kami seorang wanita yang bernama Thalhah bekas budak bani Fazarah, dari seorang budak mereka yang bernama 'Aqilah dari Salamah binti al-Hur dia berkata, "Saya mendengar Rasulullah saw bersabda: "Sungguh, di antara tanda-tanda hari Kiamat, atau sejelek-jelek ciptaan adalah ketika ahli masjid saling tolak menjadi imam hingga mereka tidak mendapati seorang imam yang memimpin mereka salat."

Hadis ini berkualitas daif dikarenakan dua rawinya majhul, tidak diketahui keterangannya sesuai dengan yang dikatakan al-Hafiz ibn Hajar.

${ }^{17}$ Alih-alih menerangkan perihal kualitas hadis akun haditsku justru memberikan catatan, "Semoga ini bukan kita ya (emoticon sedih). Jangan lupa untuk selalu like postingan kami dan juga tinggalkanlah komentar meski hanya sekedar emoticon (emoticon senyum)." Kalimat pertama adalah bentuk ungkapan dari pengelola

${ }^{15}$ Lihat Yunus Yusoff dan dkk, "Adopting Hadith Verification Techniques in to Digital Evidence Authentication," Journal of Computer Science Vol. 6, no. 6 (2010); Lihat juga Muhammad Al-Fatih Suryadilaga, "Kajian Hadis Di Era Global," Esensia Vol. 15, no. 2 (2014); Lutfi Maulana, "Periodisasi Perkembangan Studi Hadis: Dari Tradisi Lisan/Tulisan Hingga Berbasis Digital," Esensia Vol. 17, no. 1 (2016).

${ }^{16}$ Hanbal, Musnad Ahmad, Juz 45:h.112.

${ }^{17}$ Hanbal, Juz 45:h.112. 
akun untuk membentuk emosi pembaca konten. Hal ini karena pada dasarnya banyak pemuda yang tidak atau belum berani menjadi imam. Fenomena ini sering terjadi di kalangan pemuda dengan pengetahuan keagamaan yang kurang mumpuni, mereka malu akan bacaan salat mereka. Ungkapan pengelola akun sontak memancing mereka untuk merespons setidaknya kejadian yang pernah mereka alami. Tidak mengherankan jika seorang pengguna kemudian menandai beberapa temannya karena riwayat ini seakan menjurus pada mereka.

Dari kolom komentar terlihat bagaimana para pengguna menyikapi konten tersebut sebagai dalil utama dikarenakan tidak adanya keterangan bahwa hadis tersebut memiliki kualitas daif. Emosi mereka tergerak disertai dengan penerimaan paripurna akan muatan konten dikarenakan keyakinan bahwa itu adalah hadis Nabi saw. Tidak berhenti pada penerimaan mereka juga menyebarkan konten ini dengan praktik menandai teman mereka yang lain dan begitu seterusnya. Pengelola akun tidak hendak mengklarifikasi adakah unggahannya sahih atau tidak, bullshit. Ke-bullshit-an ini -bukan hanya kontennyayang kemudian viral dan menjadi meme. Kolom komentar tersebut juga menunjukkan lemahnya upaya pemuda dalam melakukan pengecekan ulang terhadap informasi yang didapatkan. Terlebih pada konten-konten agama yang notabene dogmatis, penalaran mereka cenderung sederhana, bersahaja, dan menerima.

\section{Probabilitas Komodifikasi Label Islam}

Sebelum masa internet salah satu media penyedia konten informasi dan hiburan untuk masyarakat adalah televisi. Rachmat Kriyantono menyatakan bahwa pangsa pasar televisi yang luas sebagai lokus media kabel terkadang dapat menjadi perpanjangan tangan para kapitalis. ${ }^{18}$ Pun juga dengan Instagram yang di era serba internet ini berperan sebagai media bagi para pengrajin konten kreatif tidak lepas dari jerat komodifikasi. Jumah pengikut dalam Instagram seperti halnya rating di dunia pertelevisian. Akun dengan jumlah pengikut banyak akan dibanjiri order dari para pengiklan. Sehingga setiap akun

${ }^{18}$ Lihat Rachmat Kriyantono, "Pemberdayaan Konsumen Televisi Melalui Keterampilan Media Literacy dan Penegakan Regulasi Penyiaran," Jurnal Penelitian Komunikasi Vol. 10, no. 21 (2007). 
akan berupaya keras untuk konsisten mengunggah konten fenomenal karena like dan komentar menjadi tolok ukur 'viralitas' karya mereka.

Untuk menunjang itu konten kreator pun memakai logika pasar layaknya media cetak dan televisi. Mereka berlomba dalam menyikapi isu yang tengah hangat di samping selalu mematangkan brand yang mereka bangun dengan konten timeless sesuai dengan visi-misi mereka. Terlebih Instagram memiliki prospek market yang jelas yakni pemuda. Akh Muzakki pun mengakui jika remaja Muslim menjadi segmen pasar yang prospektif dengan adanya bukti kenaikan konsumsi publikasi baik cetak maupun non-cetak. ${ }^{19}$ Konstruksi, konsumsi, dan kontestasi konten menjadi bagian dari globalisasi sekaligus respons atasnya seperti yang dinyatakan Ronald Lukens-Bull. Penulis pun sepakat dengan Lukens-Bull jika kapitalisme masa kini mampu terlibat pada ideologisasi komoditas dan komodifikasi ideologi. ${ }^{20}$

Platform Instagram tidak seperti media cetak atau televisi yang memaksa konsumennya untuk melihat iklan. Setidaknya media cetak dan televisi dapat menciptakan kepercayaan melalui persuasi yang dilakukan terus menerus hingga terbentuk folk knowledge seperti yang dikatakan oleh Marian Friestad. Istilah folk knowledge ini sendiri tidak jauh berbeda dengan meme yakni perangkat keyakinan-keyakinan yang terkontruksi secara sosial tercipta dari tahun ke tahun dari ruang persepsi privat dan komunikasi sosial mengenai persuasi. ${ }^{21}$ Menyatakan kedua istilah tersebut sama adalah bentuk simplifikasi. Terdapat perbedaan antara folk knowledge dan meme hanya ada pada kata persuasi. Istilah pertama lebih menitik beratkan pembahasan pada upaya bagaimana ide itu menyebar. Sementara yang terakhir lebih condong menyoroti ide itu sendiri bagaimanapun cara dan upayanya. Dari sini dapat dipahami bahwa upaya persuasi lewat iklan bertujuan

19 Baca Akh. Muzakki, "Teen Islam: The Rise of Teenagers-Segmented Islamic Transmission through Popular Media in Indonesia," Journal of Indonesian Islam Vol. 15, no. 1 (2014).

${ }^{20}$ Ronald Lukens-Bull, "Commodification of Religion and the Religification of Commodities: Youth Culture and Religious Identity," dalam Religious Commodification in Asia: Marketing Gods, ed. oleh Pattana Kitiarsa (London: Routledge, 2008), h.220.

${ }^{21}$ Lihat Marian Friestad dan Peter Wright, "Persuation Knowledge: Lay People's and Researchers' Beliefs about the Psychology of Advertising," Journal of Consumer Research Vol. 22, no. Juni (1995). 
untuk membentuk folk knowledge. Adapun konten iklan itu sendiri dapat menjadi meme jika berhasil tersebar.

Respons dari pengguna Instagram ketika mendapati konten iklan bervariasi bergantung pada penyajian konten itu sendiri. Sementara perencanaan kreasi konten sepenuhnya menjadi tanggung jawab pengiklan. Sehingga semakin kreatif pengiklan maka akan semakin banyak respons yang didapat konten iklannya. Peluang pengiklan untuk melakukan komodifikasi ideologi sah dianggap sebagai kreativitas, meskipun secara normatif dianggap tidak atau kurang terpuji.

Agama yang menjadi ladang basah bagi para komodikator tidak dapat diforsir berlebihan dalam platform Instagram. Hal ini karena sistem tayang pada Instagram tidak dapat diulang berkali-kali. Akun yang terlalu sering mengunggah konten yang sama berulang kali berisiko dinilai oleh pengguna Instagram sebagai akun yang tidak atau kurang kreatif. Sehingga sistem iklan pun tidak dapat dijalankan seperti halnya pada media cetak atau televisi yang mengandalkan konten yang sama dengan rasio tayang berulang kali. Untuk itu mereka membutuhkan jasa akun populer sebagai media iklan mereka. Pengiklanan pun berkisar pada konten produk dan penyebutan akun milik pengiklan. Tugas akun populer hanya mendongkrak jumlah pengikut akun pengiklan dengan cara menyertakan tanda laman akun pengiklan pada konten unggahan.

Para pengikut akun kreatif cenderung lebih menyukai dan merespons konten non-iklan daripada konten iklan. Di atas telas disebut mengenai konten baper dan nir-baper sebagai perbandingan konten kreatif mana yang lebih banyak direspons oleh pengguna. Dalam hal ini tingkat respons pengguna Instagram menempatkan posisi konten iklan berada di bawah konten nir-baper. Para pengguna yang cenderung menginginkan konten kreatif dari akun memunyai kebebasan mutlak dalam memilih. Dalam kasus tertentu respons yang didapat dari konten iklan dapat meningkat drastis dengan promosi berbagi hadiah. Artinya responsden bersikap pragmatis menyikapi konten yang mereka nilai pragmatis. 


\section{Kesimpulan}

Bentukan identitas dari meme pada platform Instagram mutlak bergantung pada konten apa yang digemari oleh penggunanya. Kegelisahan apa yang tengah melingkupi pengguna akan memengaruhinya dalam memilih dan merespons konten tertentu. Dalam kasus akun Muslim populer di Nusantara para pengguna cenderung lebih responsif ketika bersinggungan dengan konten baper.

Di sisi lain konten Instagram yang cenderung pada muatan informasi pendek berpengaruh pada pola pikir penggunanya yang juga makin memendek. Kata-kata bijak tertentu menjadi lahapan sehari-hari tanpa perlu dicari apakah itu benar atau tidak. Poin penting bagi mayoritas pengguna adalah kata-kata itu indah, memukau, dan berpahala khusus untuk konten bermuatan religi. Dalah hal ini meme menyebar secara liar sehingga butuh filter berupa klarifikasi dan pengetahuan akan muatan konten.

Budaya konsumerisme dalam Instagram pun sangat bergantung pada pengguna. Jika pengguna tersebut secara berkesinambungan merespons konten iklan maka lamannya akan dipenuhi dengan daya tarik konsumtif. Sementara bagi pengguna yang tidak tertarik dengan konten iklan secara otomatis konten iklan tidak akan muncul dalam lamanya. [.] 


\section{Referensi}

Aminuddin, Ahmad Taqwim. "Instagram Bingkai Kasus Agama Di Media Sosial.” Jurnal The Mesengger Vol. 9, no. 2 (Juli 2017).

Ball, James. Post-Truth: How Bullshit Conquered The World. London: Biteback Publishing, 2017.

Brodie, Richard. Virus of The Mind: The New Science of The Meme. London: Hay House, 2009.

Chesher, Chris. "Between Images and Information: The iPhone Camera in the History of Photography." Dalam Studying Mobile Media: Cultural Technologies, Mobile Communication, and the iPhone, disunting oleh Larissa Hjorth, Jean Burgess, dan Ingrid Richardson. London: Routledge, 2012.

Dawkins, Richard. The Selfish Gene. Oxford: Oxford University Press, 2006.

Frankfurt, Harry G. On Bullshit. Princeton: Princeton University Press, 2005.

Friestad, Marian, dan Peter Wright. "Persuation Knowledge: Lay People's and Researchers' Beliefs about the Psychology of Advertising." Journal of Consumer Research Vol. 22, no. Juni (1995).

Hanbal, Ahmad bin Muhammad bin. Musnad Ahmad. Disunting oleh Syuaib al-Arnaut. Vol. Juz 45. Beirut: Resalah Publisher, 2001.

Highfield, Tim, dan Tama Leaver. "A Methodology for Mapping Instagram Hashtags." Journal of Queesnland University of Technology Vol. 20, no. 1 (2015).

Kriyantono, Rachmat. "Pemberdayaan Konsumen Televisi Melalui Keterampilan Media Literacy dan Penegakan Regulasi Penyiaran." Jurnal Penelitian Komunikasi Vol. 10, no. 21 (2007).

Lovheim, Mia. "Identity." Dalam Digital Reigion: Understanding Religious Practice in New Media World, disunting oleh Heidi A. Campbell. London: Routledge, 2013.

Lukens-Bull, Ronald. "Commodification of Religion and the Religification of Commodities: Youth Culture and Religious Identity." Dalam Religious Commodification in Asia: 
Marketing Gods, disunting oleh Pattana Kitiarsa. London: Routledge, 2008.

Lutfi Maulana. "Periodisasi Perkembangan Studi Hadis: Dari Tradisi Lisan/Tulisan Hingga Berbasis Digital." Esensia Vol. 17, no. 1 (2016).

McComiskey, Bruce. Post-Truth Rethoric and Composition. Logan: Utah State University Press, 2017.

Muzakki, Akh. "Teen Islam: The Rise of Teenagers-Segmented Islamic Transmission through Popular Media in Indonesia." Journal of Indonesian Islam Vol. 15, no. 1 (2014).

Nilan, Pam, dan Michelle Mansfield. "Youth culture and Islam in Indonesia." Wacana Vol. 15, no. 1 (2014).

Nisa, Eva F. "Creative and Lucrative Da'wa: The Visual Culture of Instagram amongst Female Muslim Youth in Indonesia." Dalam Asiascape: Digital Asia, Vol. Vol. 5. Leiden: Brill, 2018.

Suryadilaga, Muhammad Al-Fatih. "Kajian Hadis Di Era Global." Esensia Vol. 15, no. 2 (2014).

Yusoff, Yunus, dan dkk. "Adopting Hadith Verification Techniques in to Digital Evidence Authentication." Journal of Computer Science Vol. 6, no. 6 (2010).

Zappavigna, Michele. "Social Media Photography: Construing Subjectivity in Instagram Images." Sage Journa: Visual Communication Vol. 15, no. 3 (2016).

Diakses 6 Juli 2018. http://www.statista.com/statistics/578364/ countries-with-most-instagram-users/. 